\title{
Viability and DNA Damage of Buccal Mucosa Cells in Patients Exposed to Panoramic X-ray
}

\section{ARTICLE INFO}

Submitted: 02/03/2021

Accepted: 27/05/2021

Online: 22/09/2021

\author{
Ryna Dwi Yanuaryska*, Afit Aditya Atmoko, Isti Rahayu Suryani, Rurie \\ Ratna Shantiningsih
}

Department of Dentomaxillofacial Radiology, Faculty of Dentistry, Universitas Gadjah Mada, Yogyakarta 55281, Indonesia

*Corresponding author: ryanuaryska@ugm.ac.id

To cite this article: Yanuaryska RD, Atmoko AA, Suryani IR, Shantiningsih RR (2021). Viability and DNA damage of buccal mucosa cells in patients exposed to panoramic X-ray. Arch Orofac Sci, 16(Supp.1): 43-49. https://doi.org/10.21315/aos2021.16.s1.8

To link to this article: https://doi.org/10.21315/aos2021.16.s1.8

\begin{abstract}
Panoramic X-ray is well known to cause DNA damage and induces cellular death. The aim of the present study was to evaluate the cytotoxicity of radiation exposure from panoramic radiography on human buccal mucosa cells by assessing the cell viability using the simple-trypan blue exclusion test. The genotoxicity effect was evaluated by assessing comet assay score. This research included a total of 20 healthy patients who had panoramic radiography for a routine dental examination. Buccal mucosa cells were collected from all participants before X-ray exposure and at $30 \mathrm{~min}$ or $24 \mathrm{~h}$ after exposure in Groups 1 and 2, respectively, and subjected to a comet assay and trypan blue exclusion test to assess cell viability and DNA damage. Cell viability was calculated as the ratio of live (translucent) to total counted cells. Comet assay output images were analysed using OpenComet software and a visual score by measuring the percentages of tail DNA and summing the visual score, respectively. A statistically significant $(p<0.05)$ reduce in cell viability was observed at $30 \mathrm{~min}$ after exposure, furthermore there is no more reduction after $24 \mathrm{~h}$. Both comet assay measurements showed a significant $(p<0.05)$ increase in the percentage of tail DNA and visual score at $30 \mathrm{~min}$ after exposure, then tend to decrease after $24 \mathrm{~h}$ of exposure, although it was not significant $(p>0.05)$. The results showed that panoramic radiography interfered cell viability and induced DNA damage in buccal mucosa cells within $30 \mathrm{~min}$ after exposure, but these effects were ceased after $24 \mathrm{~h}$.
\end{abstract}

Keywords: Buccal mucosa; cell viability; comet assay; DNA damage; panoramic radiography

\section{INTRODUCTION}

Panoramic radiograph provides an overall facial image including both the maxillary and the mandibular dental arches and their supporting structures. The dose used in panoramic radiography is relatively low, about 2.7 to $38 \mu \mathrm{SV}$. However, this dose is below the radiation exposure dose limit as required by the International Commission on Radiological Protection (ICRP) of $0.3 \mathrm{mSv}$. Nonetheless, low doses of $\mathrm{X}$-ray radiation have an adverse effect and may produce biological changes in the living tissues. ICRP for radiation safety makes conservative assumption that the biological damage caused by ionising radiation is related to radiation exposure, regardless of the size of the dose. Therefore, all doses of radiation are considered harmful (Lee et al., 2014).

Research on the effects of panoramic radiography has been widely done (Cerqueira et al., 2008; Angelieri et al., 2010; Ribeiro, 
2012) and showed that panoramic radiography causes chromosomal damage, nuclear changes and cell death. In agreement with our previous research, panoramic X-ray radiation induced double-strand breaks (DSBs) in buccal mucosa cells within $30 \mathrm{~min}$ after exposure (Yanuaryska, 2018). Beside DNA damage, other interesting discoveries by Cao et al. (2015) in the experiment using Saccharomyces cerevisiae showed that changes in cell membrane integrity and permeability were induced by X-ray irradiation.

Saccharomyces cerevisiae ( $S$. cerevisiae) is one of the most well-known eukaryotic models as it shares a complex intracellular organisation with the higher eukaryotes. This gives advantages in the study of cellular processes such as basic biology of the cell cycle, membrane trafficking, lipid metabolism and many other cellular systems (Feyder et al., 2015). X-ray irradiation induces significant damage to cell membranes of $S$. cerevisiae, in conjunction with a decrease in cell viability (Cao et al., 2015). To the best of our knowledge, the effects of X-ray irradiation from panoramic radiography on cell viability of human buccal cells have not yet been investigated.

Damage to cell membranes can be assessed by measuring the protein permeability, diffusion rates of nucleic acids, and staining with specific fluorescent dyes (Cao et al., 2015). At the same time, these methods are typically laborious and time-consuming. Therefore, the dye exclusion test is used to determine the number of viable cells present in buccal mucosa cells from patients exposed to $\mathrm{X}$-ray via panoramic radiography. It is based on the principle that living cells have intact cell membranes which drive out certain dyes, such as trypan blue, while dead cells do not have it (Strober, 2015).

\section{MATERIALS AND METHODS}

\section{Subjects}

The current study was conducted after obtaining approval from The Medical and Health Research Ethics Committee, Faculty of Medicine, Universitas Gadjah Mada (UGM) and Dr. Sardjito General Hospital (KE/FK/0649/EC/2018). Furthermore, signed informed consent from each participant from a total of 20 participants who underwent panoramic radiography for diagnosis and treatment in Professor Soedomo Dental Hospital, UGM, Indonesia was also taken. All participants were required to meet the following inclusion criteria: (1) Good apparent health, with no smoking or alcohol consumption habit; (2) Age between 18 and 25 years; (3) No lesions in the cheek mucosa; (4) No use of mouthwash; and the exclusion criteria: (1) The presence of systemic diseases or being differently abled; (2) Radiographic exposure for at least two weeks prior to the study. Each participant was exposed to radiation via conventional panoramic radiography which was performed using Yoshida Panoura Deluxe system (The Yoshida Dental MFG. Co., Ltd., Tokyo, Japan) with following exposure parameters: $90 \mathrm{kVp}, 8-10 \mathrm{~mA}$, $20 \mathrm{~s}$.

The participants were divided into two groups. Buccal mucosa samples were collected from both groups prior to radiation exposure and at $30 \mathrm{~min}$ or $24 \mathrm{~h}$ after radiation exposure in Groups 1 and 2, respectively. After gently rinsing the mouth with distilled water, cells were obtained by scraping the inside cheek of the mouth with a cytobrush. The cytobrush was then agitated in a vortex for $30 \mathrm{sec}$ in a tube containing phosphate-buffered saline (PBS). The resulting buccal cell suspension was centrifuged at $2,500 \mathrm{rpm}$ and $4^{\circ} \mathrm{C}$ for $10 \mathrm{~min}$, after which the supernatant was removed, and the cell pellet was suspended in $40 \mu \mathrm{L}$ of cold PBS. 


\section{Trypan Blue Exclusion Test}

The cell suspension $(10 \mu \mathrm{L})$ was mixed by trypan blue $0.4 \%$ (Sigma Aldrich, Darmstadt, Germany) and the cells were counted using an Improved Neubauer hemocytometer (Paul Marienfeld GmbH \& Co. KG, Lauda-Konigshofen, Germany). The numbers of live (translucent) and dead (stained) cells were determined by a bright field microscope $(200 \times)$. Cell viability was calculated as the ratio of live to total counted cells.

\section{Comet Assay}

The comet assay was performed using an Oxiselect Comet Assay Kit STA-351 (Cell Biolabs, San Diego, CA, USA) according to the manufacturer's instruction. The cell suspension $(30 \mu \mathrm{L})$ was added to comet agarose (ratio $\mathrm{v} / \mathrm{v}$ 1:10) then transferred onto the Oxiselect Comet Slide at once and placed on aluminium foil coated container at $4^{\circ} \mathrm{C}$ for $15 \mathrm{~min}$. The slide was then soaked in a cell lysis buffer at $4^{\circ} \mathrm{C}$ for $60 \mathrm{~min}$. Lysis buffer was removed and replaced with a cold alkaline solution at $4^{\circ} \mathrm{C}$ for $30 \mathrm{~min}$. The slides were then placed in horizontal chamber electrophoresis containing alkaline electrophoresis solution and run at $18 \mathrm{~V}$, $300 \mathrm{~mA}$ for $20 \mathrm{~min}$. The slides were moved into a clean container containing cold water and washed $3 \times$. The final washing was done with cold ethanol $70 \%$ then placed on dry and clean containers to allow drying completely. Once the agarose and slide were completely dry, $100 \mu \mathrm{L}$ of Vista Green DNA dye was added to the slide and allowed to stand for $15 \mathrm{~min}$ at room temperature. The slide was observed under fluorescence microscopy (Leica, Germany) connected to the camera and computer. DNA damage was determined by measuring the tail DNA \% of at least 50 to 100 cells per sample with OpenComet software 1.3 (Gyori et al., 2014) and was also compared with visual scores (Collins et al., 2008).

\section{Data Analysis}

Repeated ANOVA was performed to compare if there were differences in tail DNA $\%$ and cell viability between the groups: before, after $30 \mathrm{~min}$, after $24 \mathrm{~h}$. To assess the differences in visual scores of DNA damage between the groups, we used the non-parametric test, Friedman test. Statistical analysis was performed in IBM SPSS Statistics for Windows version 22.0 and a $p$-value of less than 0.05 was considered statistically significant with a $95 \%$ confidence interval.

\section{RESULTS}

Panoramic X-ray is known to have cytotoxic and genotoxic effects on the cell. To assess the cytotoxic effect, we measured cell viability by using trypan blue exclusion in human buccal mucosa cells at before, $30 \mathrm{~min}$, and $24 \mathrm{~h}$ after $\mathrm{X}$-ray exposure. Viable cells marked as translucent cells, meanwhile the nonviable cells appear blue as a consequence of taking up trypan blue (Fig. 1[a]). Panoramic X-ray significantly reduced cell viability (Fig. 1[b]) in $30 \mathrm{~min}$ after exposure which remained after $24 \mathrm{~h}$.

Genotoxic effect of panoramic X-ray was proved by measuring DNA damage in the comet assay image. Damaged cellular DNA was separated from intact DNA, yielding a typical comet shape under a microscope (Fig. 2[a]). As demonstrated in Fig. 2(b), panoramic X-ray significantly increase the percentage of tail DNA to $16 \%$ at $30 \mathrm{~min}$ after exposure, then slightly decrease at $3 \%(p>0.05)$ after $24 \mathrm{~h}$ of exposure. The percentage of tail DNA is a commonly used parameter to analyse comet assay results. Additionally, the different approaches were used in this study, i.e., visual scoring, to confirm the data obtained from OpenComet software. In visual scoring, comets were classified into five categories: 0 representing undamaged cells (no or barely detectable tails) and 1 to 4 representing damaged 
(a)

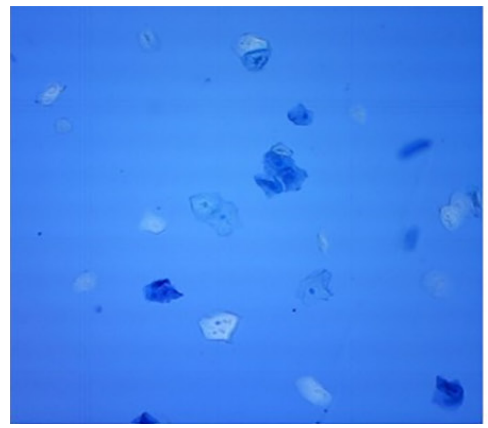

Before

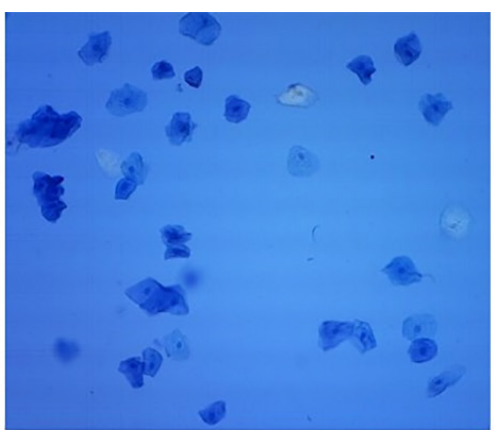

After $30 \mathrm{~min}$

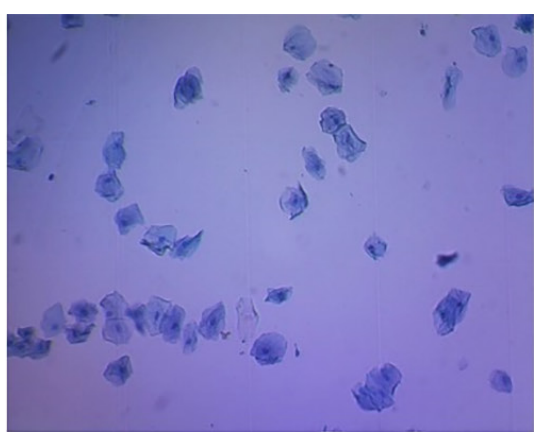

After $24 \mathrm{~h}$

(b)

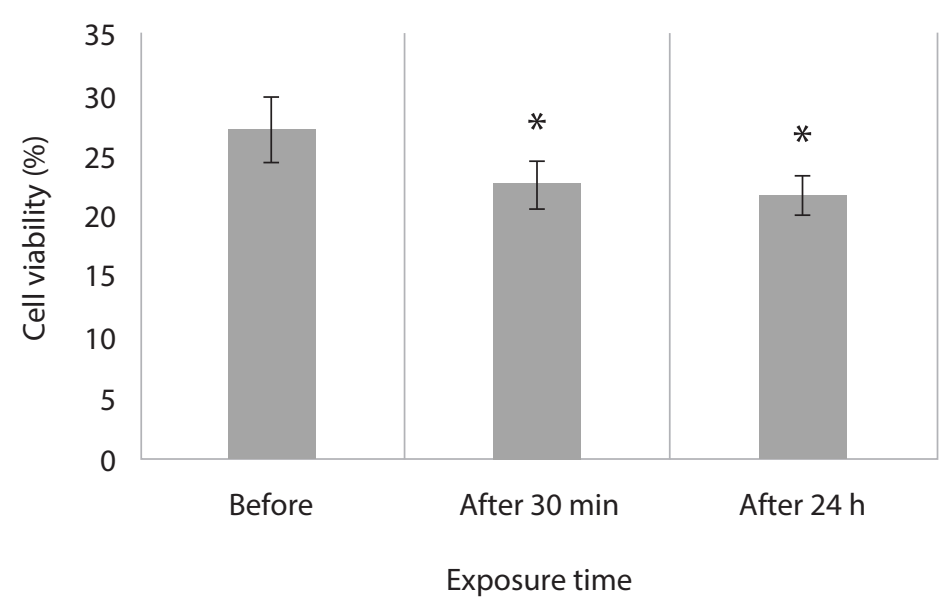

Fig. 1 The viability of human buccal mucosa cells. (a) Representative photomicrograph of cells that were stained with trypan blue (100x magnification). Note the increase of dead (stained) cells after $30 \mathrm{~min}$ and $24 \mathrm{~h}$ compared with before exposure; (b) Quantification of the cell viability and there was significant difference (* $p<0.05)$ compared with before exposure.

cells by increasing relative tail intensities (Collins et al., 2008; Ganapathy et al., 2016). The samples obtained before exposure consisted of undetectable and barely detectable comet shape, on the other hand, after $30 \mathrm{~min}$ and $24 \mathrm{~h}$ of exposure, mild and moderate comet shape were superiority found. Extensive comet shape was rarely found in those samples. Summing the scores ( 0 to 4 ) of 60 cells per sample gave an overall score of between 0 to 240 (no units), which was used for statistical analysis. Fig. 2(c) illustrates the evidence of visual scoring exhibit a trend in DNA damage in coherence with the tail DNA percentage. Visual score rose around $24 \%$ at $30 \mathrm{~min}$ after exposure, then declined by about $6 \%(p>0.05)$ after $24 \mathrm{~h}$ of exposure.

\section{DISCUSSION}

This study aimed to evaluate the cytotoxic and genotoxic effect of panoramic X-ray in human buccal mucosa cells by measuring the cell viability and DNA damage. Researchers had worked on the micronucleus test and nuclear alteration such as karyorrhexis, pyknosis and karyolysis (Angelieri et al., 2007; Ribeiro et al., 2011; Preethi et al., 2016). In this present study, the different approaches were used, which no such study had reported previously. The simple trypan blue exclusion and comet assay were used to evaluate the effects. There was only one literature found about X-ray effect on membrane permeability and integrity. The research was conducted on $S$. cerevisiae 
(a)
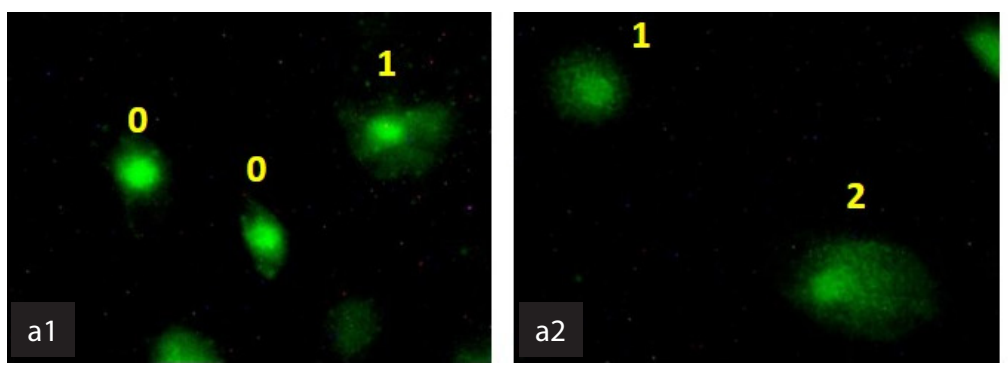

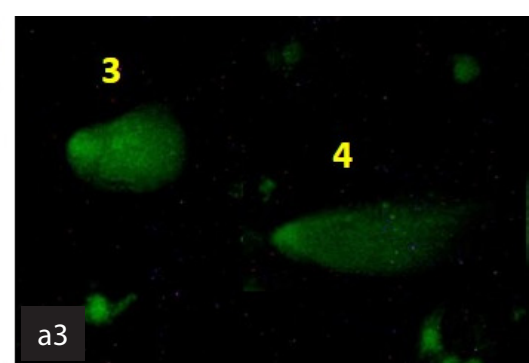

(c)

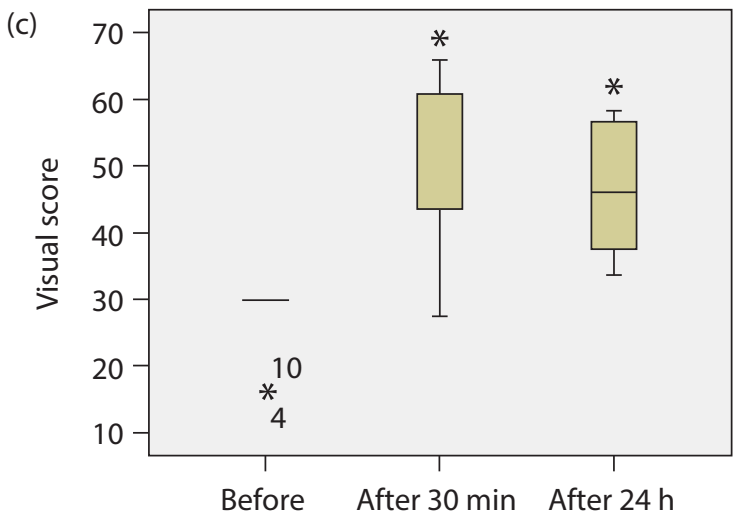

Exposure time

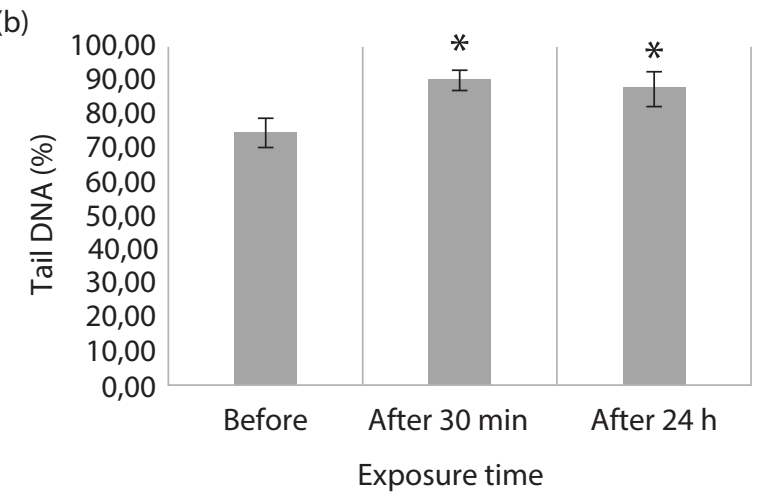

Fig. 2 Detection of DNA damage by comet assay. (a) Representative fluorescence microscopy images (100x magnification) in buccal mucosa cells from (a1) before- and (a2) after $30 \mathrm{~min}$ or (a3) $24 \mathrm{~h}$ of exposure. Comet shape is undetectable in 0 , barely detectable in 1 , mild detected in 2 , moderate in 3 , and extensive in 4; 100× magnification; (b) Quantification of tail DNA (\%) in comet assay image measured by OpenComet software; (c) Quantification of DNA damage in comet assay image by the visual score and there was significant difference $\left.{ }^{*} p<0.05\right)$ compared with before exposure.

which served as a eukaryotic model in radiation biology studies. X-ray irradiation increases permeabilised cell number and decrease overall esterase activity thus resulting increase of non-viable cell numbers (Cao et al., 2015). Those results may explain the decrease of cell viability in buccal mucosa cells at $30 \mathrm{~min}$ after panoramic $\mathrm{X}$-ray exposure. Ionising radiation leads to membrane depolarisation, i.e., displacement of the negative charge from intracellular outward cells so that the charge inside the cell becomes less negative (Somosy, 2000).

Cell permeabilisation and loss of metabolic activity as a result of X-ray irradiation may be an irreversible phenomenon (Cao et al., 2015). The number of negatively charged on the surfaces of human fibroblasts reduced significantly within $1 \mathrm{~min}$ after
$\mathrm{X}$-irradiation, in the dose range from 0.25 to $2.5 \mathrm{~Gy}$, then recovered within $1 \mathrm{~h}$. The reversibility of radiation-induced changes depends on the cell type and the source of radiation (Somosy, 2000). Therefore, it would be reasonable that there was no significant difference $(p>0.05)$ on cell viability at $30 \mathrm{~min}$ and $24 \mathrm{~h}$ after exposure. This may be due to an adaptive response of buccal mucosa cells induced by exposure to $\mathrm{X}$-ray radiation. Adaptive responses such as protection against reactive oxygen species, DNA repair and elimination of genomically damaged cells, are activated by low doses of ionising radiation that trigger repair and protective processes to prevent further damage (Desouky et al., 2015). These phenomena coincide with DSBs as showed in the comet assay results. 
Panoramic X-ray induced DNA damage within $30 \mathrm{~min}$ after exposure and slowly repaired during $24 \mathrm{~h}$. This fact could theoretically be explained that cells have mechanisms in the body which maintain the repair of DNA breaks. DSBs are primarily repaired by one of two pathways, nonhomologous end-joining (NHEJ) and homologous recombination (HR), although the choice of the pathway is not fully understood. However, heavy ion induced DSBs, which are repaired slowly, are more often repaired by HR, whereas X- or $\gamma$-ray induced breaks are repaired via NHEJ (Jeggo et al., 2011). The exact timing of initial DNA repair remains unclear. However, two DNA damage response molecules, $\gamma-\mathrm{H} 2 \mathrm{AX}$, and $\mathrm{pChk} 2$ were detected in time range around $0.1 \mathrm{~h}$ to $48 \mathrm{~h}$ and $0.25 \mathrm{~h}$ to $32 \mathrm{~h}$, respectively, after ionising radiation exposure from intraoral dental radiographs (Yoon et al., 2009). Therefore, it could be assumed that there was a repair process of DSBs induced by panoramic X-ray during $24 \mathrm{~h}$ after exposure.

\section{CONCLUSION}

The present study gave a new insight regarding the panoramic X-ray effect on cell viability and DNA damage. The results strongly suggested that panoramic $\mathrm{X}$-ray discharged cell viability and induced DSBs within $30 \mathrm{~min}$ after exposure. Even though at low doses, panoramic X-ray induce cytotoxicity and genotoxicity in human buccal mucosa cells. Radiation protection in the patient undergoing panoramic radiography should be considered as protecting the human health per se. However, further analyses are required to investigate the associations of cell viability and DNA damage therewith the involved molecules.

\section{ACKNOWLEDGEMENTS}

This work was supported by Dana Masyarakat grant (Ref. No. 4463/UN1/ KG/Set.KG/LT/2018) from the Faculty of Dentistry, Universitas Gadjah Mada, Indonesia.

\section{REFERENCES}

Angelieri $\mathrm{F}$, de Cássia Gonçalves Moleirinho T, Carlin V, Oshima CT, Ribeiro DA (2010). Biomonitoring of oral epithelial cells in smokers and non-smokers submitted to panoramic X-ray: Comparison between buccal mucosa and lateral border of the tongue. Clin Oral Investig, 14(6): 669-674. https://doi.org/10.1007/s00784-009-0345-6

Angelieri F, de Oliveira GR, Sannomiya EK, Ribeiro DA (2007). DNA damage and cellular death in oral mucosa cells of children who have undergone panoramic dental radiography. Pediatr Radiol, 37(6): 561-565. https://doi.org/10.1007/s00247007-0478-1

Cao G, Zhang M, Miao J, Li W, Wang J, Lu $\mathrm{D}$ et al. (2015). Effects of X-ray and carbon ion beam irradiation on membrane permeability and integrity in Saccharomyces cerevisiae cells. I Radiat Res, 56(2): 294304. https://doi.org/10.1093/jrr/rru114

Cerqueira EM, Meireles JR, Lopes MA, Junqueira VC, Gomes-Filho IS, Trindade S et al. (2008). Genotoxic effects of X-rays on keratinized mucosa cells during panoramic dental radiography. Dentomaxillofac Radiol, 37(7): 398-403. https://doi.org/10.1259/ $\mathrm{dmfr} / 56848097$

Collins AR, Oscoz AA, Brunborg G, Gaivão I, Giovannelli L, Kruszewski $M$ et al. (2008). The comet assay: Topical issues. Mutagenesis, 23(3): 143-151. https://doi .org/10.1093/mutage/gem051

Desouky O, Ding N, Zhou G (2015). Targeted and non-targeted effects of ionizing radiation. F Radiat Res Appl Sci, 8(2): 247254. https://doi.org/10.1016/j.jrras.2015.03 .003 
Feyder S, De Craene JO, Bär S, Bertazzi DL, Friant S (2015). Membrane trafficking in the yeast Saccharomyces cerevisiae model. Int f Mol Sci, 16(1): 1509-1525. https://doi.org/10.3390/ijms 16011509

Ganapathy S, Muraleedharan A, Sathidevi PS, Chand P, Rajkumar RP (2016). CometQ: An automated tool for the detection and quantification of DNA damage using comet assay image analysis. Comput Methods Programs Biomed, 133: 143-154. https://doi.org/10.1016/j.cmpb.2016.05.020

Gyori BM, Venkatachalam G, Thiagarajan PS, Hsu D, Clement MV (2014). OpenComet: An automated tool for comet assay image analysis. Redox Biol, 2: 457-465. https://doi.org/10.1016/j.redox.2013.12.020

Jeggo PA, Geuting V, Löbrich M (2011). The role of homologous recombination in radiation-induced double-strand break repair. Radiother Oncol, 101(1): 7-12. https://doi.org/10.1016/j.radonc.2011.06 .019

Lee KF, Weng JT, Hsu PW, Chi YH, Chen CK, Liu IY et al. (2014). Gene expression profiling of biological pathway alterations by radiation exposure. BioMed Res Int, 2014: 834087. https://doi.org/10 $.1155 / 2014 / 834087$

Preethi N, Chikkanarasaiah N, Bethur SS (2016). Genotoxic effects of X-rays in buccal mucosal cells in children subjected to dental radiographs. BDF Open, 2: 16001. https://doi.org/10.1038/bdjopen.2016.1
Ribeiro DA (2012). Cytogenetic biomonitoring in oral mucosa cells following dental. Dentomaxillofac Radiol, 41(3): 181-184. https://doi.org/10.1259/dmfr/14555883

Ribeiro DA, Sannomiya EK, Pozzi R, Miranda SR, Angelieri F (2011). Cellular death but not genetic damage in oral mucosa cells after exposure to digital lateral radiography. Clin Oral Investig, 15(3): 357-360. https:// doi.org/10.1007/s00784-010-0402-1

Somosy Z (2000). Radiation response of cell organelles. Micron, 31(2): 165-181. https:// doi.org/10.1016/s0968-4328(99)00083-9

Strober W (2015). Trypan blue exclusion test of cell viability. Curr Protoc Immunol, 111: A3.B.1-A3.B.3. https://doi.org/10.1002/ 0471142735.ima03bs 111

Yanuaryska RD (2018). Comet assay assessment of DNA damage in buccal mucosa cells exposed to $\mathrm{X}$-Rays via panoramic radiography. F Dent Indones, 25(1): 53-57. https://doi.org/10.14693/jdi.v25i1.1124

Yoon AJ, Shen J, Wu H-C, Angelopoulos C, Singer SR, Chen R et al. (2009). Expression of activated checkpoint Kinase 2 and Histone 2AX in exfoliative oral cells after exposure to ionizing radiation. Radiat Res, 171(6): 771-775. https://doi.org/10 $.1667 /$ RR1560.1 